S. Ivanov, H. Dzwigol, N. Trushkina

Corresponding Member of National Academy of Sciences of Ukraine, DrHab (Economics), Professor, ORCID 0000-0002-1205-3797, Institute of Industrial Economics of NAS of Ukraine, Kyiv,

H. Dzwigol, PhD, DrHab (Economics), Professor, ORCID 0000-0002-2005-0078, Silesian University of Technology, Poland,

N. Trushkina, PhD (Economics), ORCID 0000-0002-6741-7738, Institute of Industrial Economics of NAS of Ukraine, Kyiv

\title{
PROPOSALS FOR THE FORMATION OF A TRANSPORT AND LOGISTICS CLUSTER AS AN INSTITUTION OF REGIONAL DEVELOPMENT (ON THE EXAMPLE OF DONETSK ECONOMIC REGION)
}

\begin{abstract}
The study was carried out as part of the research work of the Institute of Industrial Economics of NAS of Ukraine "Formation of the institutional environment for the modernization of the economy of the old industrial regions of Ukraine».
\end{abstract}

Problem statement. One of the dynamic and rapid lines of development of modern regional ecosystems is transport logistics as an effective source of competitive advantages. This requires the use of new tools to improve the competitive ability of regions, including the cluster approach, the essence of which is the formation and development of logistic clusters by consolidating the efforts of the state, business, science, education in priority fields of economic activity. As international practice shows, the implementation of the cluster model of logistic activities will contribute to the reduction of total logistic costs by $12-35 \%$ as a result of reducing transport costs by $7-20 \%$ and the cost of handling operations by $20-30 \%$, as well as accelerating the speed of circulation of material resources by $20-40 \%$. Therefore, the creation of transport and logistics cluster will create favorable conditions for the growth of the volume and quality of services and create a qualitatively new model of the regional economy in the economic regions of Ukraine.

Analysis of recent publications on the problem. On the basis of generalizations of scientific publications of foreign and Ukrainian scientists it is established that they paid considerable attention:

substantiation of application of an integrated approach to supply chain management and organization of logistics processes [1-5];

development of theoretical, methodological and applied principles of formation of the system of management of balanced development of the market of logistic services as a component of the national logistics system, which allows to activate and effectively use the existing logistical potential of Ukraine [6];

defining the directions of increasing the efficiency of transport and logistics activities and key tasks and priorities of the development of the transport sector in Ukraine [7; 8; 9];

evaluation of indicators of innovative development of the transport system of Ukraine to substantiate strategic guidelines [10];

development of proposal for activation of innovative development of the transport and logistics system of Ukraine [11];

defining the components of the financial support mechanism for managing the innovative development of the transport and logistics system [12];

substantiation of conceptual provisions of strategy of development of transport system of Ukraine and measures of state policy of its implementation [13];

the development of theoretical and methodological provisions and practical recommendations for the formation of transport and logistics clusters [14-24];

identifying global trends in digitalization, which include the use of big data and cloud technologies, the proliferation of the Internet of Things, the development of robotization, the spread of 3D printing, blockchain technology and crowdsourcing [25-26; 27-29]; development of a functional scheme of digital transformation of the transport sector in Ukraine [30].

At the same time, despite such close attention to the problem outlined by scientists, it is important and necessary to carry out scientific researches in the direction 
of substantiation of conceptual provisions on modernization of transport infrastructure of Donetsk economic district with the help of the transport-logistic cluster as the «core» of the renewed transport system. All this largely determined the choice of the topic of this study and its focus.

Formulation of research. The purpose of the article is to develop proposals for the formation of a transport and logistics cluster as an institute for regional development (on the example of Donetsk economic region).

Outline of the main results and their justification. As a result of previous researches [31-36] it is proved that the development of transport and logistics system of Donetsk economic region is influenced by many factors that can be conditionally divided into 7 groups:

$$
F=\left\{\begin{array}{l}
F_{1}\left(x_{11}, x_{12}\right) ; \\
F_{2}\left(x_{21}, x_{22}\right) ; \\
F_{3}\left(x_{31}, x_{32}, x_{33}\right) ; \\
F_{4}\left(x_{41}\right) ; \\
F_{5}\left(x_{51}\right) ; \\
F_{6}\left(x_{61}\right) ; \\
F_{7}\left(x_{71}, x_{72}, x_{73}\right)
\end{array}\right\},
$$

where

$F_{1}$ - political:

$x_{11}$ - unstable political situation in the country;

$x_{12}$ - Donbass transport blockade;

$F_{2}$ - institutional:

$x_{21}$ - imperfect legislative and regulatory framework;

$x_{22}$ - lack of a regional program and strategy for the development of the transport and logistics cluster;

$F_{3}$ - investment and financial:

$x_{31}$ - insufficient financing of the transport industry;

$x_{32}$ - inefficient implementation of the public-private partnership mechanism;

$x_{33}$ - limited tools for private investment in logistics infrastructure;

$F_{4}$ - infrastructure:

$x_{41}$ - significant disruption to existing logistics infrastructure facilities;

$F_{5}$-environmental:

$x_{51}$ - insufficient application of the concept of green logistics in the transport sector;

$F_{6}$-information:

$x_{61}$ - insufficient use of information and communication technologies and tools of digital logistics;
$F_{7}$ - logistic:

$x_{71}$-ineffective organization of logistic activities;

$x_{72}-$ reducing the level of service and quality of transport and logistics services;

$x_{73}$ - reduction of cargo transportation by different modes of transport.

According to data of the State Statistics Service of Ukraine the volume of freight traffic by the Donetsk railway has decreased by $65.7 \%$ in $2000-2018$ and its share in the total Ukrainian volume of freight traffic by railways - by 27.7 percentage points or from 44.7 to $17.0 \%$. The freight turnover of the Donetsk railway has declined by $60.8 \%$ and share - by 12.4 p.p. or from 19.5 to $7.1 \%$ of the national freight turnover of public railway transport (Table 1).

Table 1

Volumes of cargo transportation and cargo turnover of the public railway transport

\begin{tabular}{|l|c|c|}
\hline Years & $\begin{array}{c}\text { Cargo dispatch, } \\
\text { million tonnes }\end{array}$ & $\begin{array}{c}\text { Cargo turnover, } \\
\text { billion tonne- } \\
\text { kilometre }\end{array}$ \\
\hline 2000 & 132.4 & 33.7 \\
\hline 2001 & 140.5 & 31.9 \\
\hline 2002 & 145.0 & 33.3 \\
\hline 2003 & 156.6 & 37.3 \\
\hline 2004 & 166.9 & 38.2 \\
\hline 2005 & 157.8 & 36.9 \\
\hline 2006 & 163.0 & 39.6 \\
\hline 2007 & 167.6 & 42.4 \\
\hline 2008 & 160.9 & 41.7 \\
\hline 2009 & 131.4 & 32.1 \\
\hline 2010 & 142.4 & 37.3 \\
\hline 2011 & 153.1 & 41.0 \\
\hline 2012 & 142.6 & 38.4 \\
\hline 2013 & 139.0 & 34.6 \\
\hline 2014 & 99.4 & 22.8 \\
\hline 2015 & 69.2 & 13.8 \\
\hline 2016 & 71.7 & 17.5 \\
\hline 2017 & 48.7 & 13.2 \\
\hline 2018 & 45.4 & 13.2 \\
\hline
\end{tabular}

Source: [37, p. 72, 101; 38, p. 46, 50].

Statistical analysis showed that the volume of cargo transportation by road in Donetsk economic region has decreased in 2018 compared to 2000 by $22.5 \%$. This is due to the decline of road freight in Lugansk region by $82.0 \%$ and Donetsk region - by $10.1 \%$. Share of cargo transportation by road of Donetsk economic region has declined from 16.1 to $9.7 \%$, it is 6.4 percentage points increase in the national volume (Table 2).

Freight turnover of road transport in Donetsk economic region has increased by 1.2 times as a result of an increase in cargo turnover in Donetsk region by 1.6 times. However, the turnover of road transport in $\mathrm{Lu}-$ gansk region has decreased by 1.8 times. Share of road transport turnover in the region has decreased by 7.8 
percentage points or from 11.4 to $3.6 \%$ in the national freight turnover (Table 3).

Table 2

Volumes of cargo transportation by road in Donetsk economic region, million tonnes

\begin{tabular}{|l|c|c|c|}
\hline \multirow{2}{*}{ Years } & \multirow{2}{*}{$\begin{array}{c}\text { Donetsk eco- } \\
\text { nomic region }\end{array}$} & $\begin{array}{c}\text { Donetsk } \\
\text { region }\end{array}$ & $\begin{array}{c}\text { Lugansk } \\
\text { region }\end{array}$ \\
\cline { 3 - 4 } 2000 & 151.4 & 125.3 & 26.1 \\
\hline 2001 & 168.5 & 129.7 & 38.8 \\
\hline 2002 & 177.0 & 145.7 & 31.3 \\
\hline 2003 & 187.6 & 137.7 & 49.9 \\
\hline 2004 & 179.1 & 147.1 & 32.0 \\
\hline 2005 & 202.3 & 170.5 & 31.8 \\
\hline 2006 & 210.8 & 182.5 & 28.3 \\
\hline 2007 & 215.4 & 188.5 & 26.9 \\
\hline 2008 & 202.3 & 174.9 & 27.4 \\
\hline 2009 & 156.4 & 131.7 & 24.7 \\
\hline 2010 & 174.1 & 149.8 & 24.3 \\
\hline 2011 & 192.6 & 166.3 & 26.3 \\
\hline 2012 & 199.1 & 174.4 & 24.7 \\
\hline 2013 & 196.8 & 168.1 & 28.7 \\
\hline 2014 & 94.9 & 68.0 & 26.9 \\
\hline 2015 & 104.3 & 77.0 & 27.3 \\
\hline 2016 & 134.7 & 118.6 & 16.1 \\
\hline 2017 & 110.0 & 105.1 & 4.9 \\
\hline 2018 & 117.4 & 112.7 & 4.7 \\
\hline
\end{tabular}

Source: [37, p. 72; 38, p. 46].

Table 3

Cargo turnover of motor vehicle in Donetsk economic regions, million tonne-kilometre

\begin{tabular}{|l|c|c|c|}
\hline \multirow{2}{*}{ Years } & \multirow{2}{*}{$\begin{array}{c}\text { Donetsk } \\
\text { economic region }\end{array}$} & $\begin{array}{c}|c| \\
\text { Donetsk } \\
\text { region }\end{array}$ & $\begin{array}{c}\text { Lugansk } \\
\text { region }\end{array}$ \\
\hline 2000 & 2189.4 & 1301.9 & 887.5 \\
\hline 2001 & 2358.8 & 1475.6 & 883.2 \\
\hline 2002 & 2762.9 & 1747.2 & 1015.7 \\
\hline 2003 & 3204.3 & 1950.4 & 1253.9 \\
\hline 2004 & 3372.4 & 2019.8 & 1352.6 \\
\hline 2005 & 3899.9 & 2202.4 & 1697.5 \\
\hline 2006 & 4263.3 & 2523.0 & 1740.3 \\
\hline 2007 & 4784.0 & 2771.1 & 2012.9 \\
\hline 2008 & 5167.6 & 2853.0 & 2314.6 \\
\hline 2009 & 4648.0 & 2458.7 & 2189.3 \\
\hline 2010 & 5603.4 & 2897.1 & 2706.3 \\
\hline 2011 & 6324.2 & 3258.1 & 3066.1 \\
\hline 2012 & 6181.9 & 3793.4 & 2388.5 \\
\hline 2013 & 7579.8 & 4393.2 & 3186.6 \\
\hline 2014 & 5915.9 & 4125.9 & 1790.0 \\
\hline 2015 & 3441.9 & 2238.3 & 1203.6 \\
\hline 2016 & 3090.6 & 2230.5 & 860.1 \\
\hline 2017 & 2844.5 & 2367.3 & 477.2 \\
\hline 2018 & 2608.1 & 2125.6 & 482.5 \\
\hline
\end{tabular}

Source: [37, p. 101; 38, p. 51].

Analytical evaluation of statistical data shows that the share of capital investment in transport and warehousing in Donetsk economic region has decreased in $2010-2018$ by 3.4 percentage points or from 7.2 to $3.8 \%$ of the total volume of capital investment in this industry.
This was due to a decrease in the share of capital investments in transport and warehousing in Donetsk region by 2.0 percentage points (from 5.7 to $3.7 \%$ ) and $\mathrm{Lu}-$ gansk region - by 1.4 percentage points (from 1.5 to $0.1 \%$ ) (Table 4).

Table 4

Capital investments in transport and warehousing in Donetsk economic region (in actual prices, million UAH)

\begin{tabular}{|l|c|c|c|}
\hline \multirow{2}{*}{ Years } & \multirow{2}{*}{$\begin{array}{c}\text { Donetsk } \\
\text { economic region }\end{array}$} & $\begin{array}{c}\text { Donetsk } \\
\text { region }\end{array}$ & $\begin{array}{c}\text { Lugansk } \\
\text { region }\end{array}$ \\
\hline 2010 & 1670.7 & 1323.8 & 346.9 \\
\hline 2011 & 3642.9 & 3341.7 & 301.2 \\
\hline 2012 & 3978.9 & 3858.7 & 120.2 \\
\hline 2013 & 1816.2 & 1662.7 & 153.5 \\
\hline 2014 & 1161.7 & 959.1 & 202.6 \\
\hline 2015 & 898.2 & 871.0 & 27.2 \\
\hline 2016 & 473.9 & 452.8 & 21.1 \\
\hline 2017 & 1715.4 & 1672.1 & 43.3 \\
\hline 2018 & 1868.0 & 1819.2 & 48.8 \\
\hline
\end{tabular}

Source: $[38$, p. 16].

The key problem for the development of the Donetsk region is the deterioration of logistical activity of the Mariupol Sea Commercial Port due to blocking the possibility of passage of vessels through the Kerch Strait. According to the analysis of statistical data the total volume of cargo processing by stevedoring companies in Mariupol seaport has decreased in 2012-2018 by $60.5 \%$. The volume of export goods has declined in 2018 compared to 2012 by $22.5 \%$. During the research period, there was a trend of growth in the volume of imported goods by stevedoring companies by 3.6 times. In 2015, the volume of transit cargoes has decreased significantly. And since 2016 transit goods have stopped (Table 5).

In view of the above, it is advisable for the transformation of the regional transport and logistic system of Donetsk economic region to develop and implement a set of proposals, which should contain the following measures:

formation of transport and logistics cluster as an effective form of partnership between business structures, scientific institutions, higher education institutions, institutions of transport and logistics infrastructure and authorities in the context of ensuring the modernization of the economy: development of a strategy for the integrated development of transport and logistics cluster; development of financial support mechanism for the management of transport and logistics cluster development, the essence of which is the application of such financial instruments as venture investment, crowdsourcing, factoring, public-private partnership based on attracting private investment, funds of credit institutions, foreign investment financial resources, grants ; development and implementation of the regional cluster model of logistics activities organization; recon- 
struction of existing and creation of new objects of proper logistics infrastructure (transport, trading, service, etc.); creation of optimal multimodal logistics chains, including through increased use of energy efficient modes of transport;

organization of logistic activity and development of port infrastructure in Mariupol seaport: attraction of private investments in technical modernization of seaport infrastructure; activation of innovative activity with application of different forms of preferences (credits, guarantees, tax privileges, subsidies) for the development of seaports; transfer of port facilities for concession or lease;

Freight handling volumes by stevedoring companies in Mariupol seaport, thousand tonnes

\begin{tabular}{|l|c|c|c|c|c|c|c|}
\hline \multirow{2}{*}{ Indicators } & \multicolumn{9}{c|}{ Years } \\
\cline { 2 - 9 } & 2012 & 2013 & 2014 & 2015 & 2016 & 2017 & 2018 \\
\hline Total volume & 14908.7 & 15499.4 & 13003.2 & 8984.0 & 7603.5 & 6514.5 & 5887.9 \\
\hline $\begin{array}{l}\text { Including } \\
\text { Export goods }\end{array}$ & 13011.3 & 14058.3 & 10853.9 & 5178.0 & 5607.6 & 5462.6 & 4929.9 \\
\hline Imported goods & 249.3 & 177.9 & 476.4 & 1321.7 & 269.8 & 936.6 & 907.5 \\
\hline Transit goods & 1635.6 & 1217.5 & 473.6 & 8.3 & - & - & - \\
\hline
\end{tabular}

Source: Information and statistical materials of the Administration of the seaports of Ukraine.

introduction of information technologies for management of transport and logistics system of economic region: introduction of «physical» internet based on the Internet of Things; development and implementation of information solutions for the delivery of the «last mile» (the use of autonomous vehicles for delivery of goods); introduction of digital crowdsourcing platforms in delivery of products to consumers using the principles of trust and cooperation between participants of logistic processes;

introduction and development of the concept of «green» logistics, which will allow to integrate ecology and economy into a single system in order to preserve the environment and modernize the regional transport and logistics system using environmentally friendly technologies; attraction of investments in the equipment and the equipment connected with environmentally friendly technologies, in the field of transport and the warehouse economy;

$$
E=\sum_{i j=1}^{n} E_{1}\left(y_{11}, \ldots, y_{18}\right)+E_{2}\left(y_{21}, \ldots, y_{24}\right)+E_{3}\left(y_{31}, \ldots, y_{34}\right) \rightarrow \max ,
$$

where

$E_{1}$ - economic effect:

$y_{11}$ - increasing the level of investment attractiveness of the territories of the region;

$y_{12}$ - increase of revenues to the budgets (regional, local) at the expense of formation of a qualitatively new model of regional economy, strengthening of competitive advantages of the region and increase of economic capacity of territorial communities in the conditions of decentralization;

$y_{13}$ - annual increase of freight transportation by rail transport by $5 \%$ and cargo turnover of Donetsk railway by $2 \%$;

$y_{14}$ - annual increase in the volume of transportation of goods by road by $6 \%$ and the turnover of road transport by $16 \%$;

$y_{15}$ - reducing logistics costs by $12 \%$ due to a $7 \%$ reduction in the cost of transport;

$y_{16}$ - reduction of the average idle of the car under one cargo operation of Donetsk railway (hours) by $25 \%$;

$y_{17}$ - ensuring favorable institutional conditions for the functioning of the logistics services market;

$y_{18}$ - improvement of transportation technology with the use of modern information and communication technologies and digital logistics; 
$E_{2}$ - social effect:

$y_{21}$ - annual growth of the average number of employees in the field of transport and storage by $1.5 \%$, including in the field of land and pipeline, water, aviation - by $1 \%$;

$y_{22}$ - job creation and employment growth (for example, as shown by good European experience, $33.3 \%$ of cluster companies have a trend of steady employment growth);

$y_{23}$ - improving the working conditions of workers employed in the field of transport and warehousing;

$y_{24}$ - reducing the level of accidents;

$E_{3}$ - ecological effect:

$y_{31}$ - ensuring almost complete decarbonization of city logistics;

$y_{32}$ - reduction of greenhouse gas emissions from transport by optimizing transport flows;

$y_{33}$ - increasing the share of electrically and environmentally friendly modes of transport;

$y_{34}$ - increasing the level of environmental safety.

Conclusions and prospects for further research. As a result of the study it was found that the formation and effective functioning of transport and logistic cluster in the Donetsk economic region is hampered by many key barriers that can be conditionally classified into the following groups, such as political, foreign economic, institutional, investment and financial, infrastructure, environmental, information, logistics. It was proved that for the effective development of transport and logistic cluster in the economic region it is reasonable to develop proposals for the creation of appropriate institutional conditions, which are to finalize the Strategies of the regional development in terms of institutional, investment and financial, organizational and economic and information support of the functioning of transport and logistic cluster using the cluster approach, as well as the Concepts of creating transport and logistic cluster and Strategies for the integrated development of transport and logistic cluster as a component of the regional transport and logistic system; implementation of the financial support mechanism, which includes exogenous and endogenous factors affecting the development of the regional transport and logistic system; the principles on which the formation of transport and logistic cluster should be based; management functions (forecasting, planning, organization, accounting, control, analysis, regulation); a set of tools governing the organization and implementation of logistic activities, as well as the provision of transport services; financial instruments (venture investment, crowdinvesting, factoring, public-private partnership on the basis of attracting private investments, funds of credit institutions, foreign investment resources, grants of international financial organizations); means (digital, information and communication technologies, software, regulatory documents).

The indicators that characterize the effectiveness of the implementation of proposals for the formation of transport and logistic cluster in the Donetsk economic region include annual growth: length of public roads (thousand $\mathrm{km}$ ) by $3.6 \%$; solid-state public roads $(\mathrm{km})$ by $1 \%$; the density of public roads with hard surface $(\mathrm{km}$ per 1 thousand $\mathrm{km}^{2}$ of the territory of the region) by $2 \%$; the average daily productivity of the locomotive (thousand tonne-kilometre gross) of the Donetsk railway by $2.4 \%$; average daily freight wagon productivity (tonnekilometre net) by $17.5 \%$; average section speed of freight train ( $\mathrm{km}$ per hour) by 1\%; the level of logistic service of consumers of services $(\%)$ by $3 \%$; the share of direct investment in transport and logistics in the total volume of direct investment in all types of economic activity of the region $(\%)$ by $2 \%$; the share of capital investments in the sphere of transport and warehouse economy in the total volume of capital investments by all types of economic activity of the region ( $\%$ by by $3 \%$.

Combination of modern cluster policy, mechanism of institutional support for the development of an integrated transport and logistic system and strategies of smart industry specializations in the context of decentralization will create the appropriate conditions for the formation of transport and logistic cluster as an effective form of partnership, strengthen the competitive advantages of the Donetsk economic region and increase the economic capacity of territorial communities.

It is planned in future to develop a cluster model of logistic activities in the economic regions of Ukraine.

\section{Literature}

1. Blaik P. Logistyka. Koncepcja zintegrowanego zarzadzania. Warszawa: Polskie Wydawnictwo Ekonomiczne, 2010. 480 s. 2. Kotler P., Keller K.L. Marketing Management. 14th edition. Upper Saddle River, New Jersey: Prentice Hall, 2014. 720 p. 3. Мэрфи Пол Р., Вуд Дональд Ф. Современная логистика. 8-е изд. Москва: ООО «И.Д. Вильямс», 2017. 720 с. 4. Бауэрсокс Дональд Дж., Клосс Дэйвид Дж. Логистика: интегрированная иепь поставок. 2-е изд. Москва: Олимп-Бизнес, 2017. 640 c. 5. Dźwigol H., Dźwigol-Barosz M. Scientific Research Methodology in Management Sciences. Financial and Credit Activity: Problems of Theory and Practice. 2018. Vol. 2. No. 25. P. 424-437. https://doi.org/10.18371/ fcaptp. v2i25.136508. 6. Григорак М.Ю. Інтелектуалізація ринку логістичних послуг: кониепиії, методологія, компетентність: монографія. Київ: Сік Груп Україна, 2017. 516 с. 7. Перебийніс В.I., Перебийніс О.В. Транспортно-логістичні системи підприємств: 
формування та функиіонування: монографія. Полтава: РВЦ ПУСКУ, 2006. 207 с. 8. Перебийніс В.I., Болдирєва Л.М., Перебийніс О.В. Транспортний менеджмент і транспортний маркетинг виробничо-комериійної діяльності: монографія. Полтава: Полтавський ун-т споживчої кооперації України, 2009. 201 с. 9. Розвиток інфраструктурних секторів як чинник реалізачії пріоритетних напрямів економічної політики України: колективна монографія / за ред. О.І. Никифорук; НАН України, ДУ «Ін-т екон. та прогнозув. НАН України». Київ, 2017. 522 с. 10. Іванов С.В., Харазішвілі Ю.М. Інноваційні фактори розвитку транспортної системи України. Вісник економічної науки України. 2017. № 2. С. 47-55. 11. Іванов С.В., Ляшенко B.I., Трушкіна Н.В. Інноваційний розвиток транспортно-логістичної системи в Україні: проблеми та шляхи їх вирішення. Інституцііональна модель інноваційної економіки: колективна монографія / за ред. B.I. Ляшенка, О.В. Прокопенко, В.А. Омельяненка; НАН України, Ін-т економіки пром-сті. Київ, 2019. С. 114-130. 12. Trushkina N. Financial ensuring mechanism of management innovative development of the transportlogistics system. Organizational-economic mechanism of management innovative development of economic entities: collective monograph / Edited by M. Bezpartochnyi, in 3 Vol. / Higher School of Social and Economic. Przeworsk: WSSG, 2019. Vol. 3. Р. 227-236. 13. Никифорук О.I. Модернізація наземних транспортних систем України: монографія. Київ: Ін-т економіки та прогнозування НАН України, 2014. 440 с. 14. Zrobek J. Marketing w klastrach logistycznych. Acta Universitatis Lodziennsis. Folia Oeconomica. 2011. No. 251. S. 5-16. 15. Szuster M. Rola klastrow we wspieraniu innowacyjnosci [The role of clusters in innovation supporting]. Ekonomiczne Problemy Uslug. 2012. No. 94. S. 311-325. 16. Смирнов I., Шматок О. Формування транспортно-логістичних кластерів у ЄС: український контекст. Вісник Київського начіонального університету імені Т.Г. Шевченка. 2012. Вип. 60. С. 14-19. 17. Попова Н.В. Кластеры как основа инновационного развития транспортно-логистической системы региона. Бизнес Информ. 2013. Вып. № 8. С. 63-67. 18. Альошинський С.С., Білан К.В. Розробка пропозицій щодо створення транспортно-логістичного кластера Харківської області. Восточно-Европейский журнал передовых технологий. 2013. № 3(3). C. 29-33. 19. Kruczek M., Zebrucki Z. Koncepcja klastrow logistycznych. Zeszyty naukowe Politechniki Slaskiej. Seria: Organizacja i zarzadzanie. 2014. No. 70. S. 229-241. 20. Кластери в економіці України: монографія / за наук. ред. М.П. Войнаренка. Хмельницький: ХНУ, ФОП Мельник А.А., 2014. 1085 с. 21. Полякова О.М. Кластерний підхід до формування інтегрованої транспортно-логістичної системи. Вісник економіки транспорту і промисловості. 2014. № 45. C. 239-244. 22. Frankowska M. Klastry logistyczne jako ogniwa globalnych lancuchow dostaw. Logistyka. 2015. No. 3. S. 5633-5637. 23. Дмуховскі Р. Поняття логістичних кластерів та ефективності економічних підприємств. Журнал європейської економіки. 2019. Т. 18. № 3(70). С. 296-306. https://doi.org/ 10.35774/jec2019.03.351. 24. Гриценко С.I. Моделювання системи цінностей еколанцюга постачань як домінанта транспортно-логістичних кластерів. Вісник економічної науки Украӥни. 2019. № 1(36). С. 31-34.
25. Гриценко В.I., Онищенко I.М. Визначення інформативності параметрів моделі прогнозування ймовірності вибору продукту в умовах «Big Data». Кибернетика и вычислительная техника. 2017. Вып. 4 (190). C. 5-18. 26. Онищенко І.М. Удосконалення методів обробки та зберігання даних за допомогою інструментів «Big Data» та Map Reduce. Економіко-математичне моделювання соиіально-економічних систем: зб. наук. праць. Київ: МННЦІТС НАН та МОН України, 2017. Вип. 22. С. 159-178. 27. Kwilinski A. Mechanism of formation of industrial enterprise development strategy in the information economy. Virtual Economics. 2018. Vol. 1. No. 1. P. 7-25. https://doi.org/10.34021/ve.2018. 01.01(1). 28. Kwilinski A. Mechanism of modernization of industrial sphere of industrial enterprise in accordance with requirements of the information economy. Marketing and Management of Innovations. 2018. No. 4. P. 116-128. http://doi.org/10.21272/ mmi.2018.4-11. 29. Kwilinski A. Implementation of Blockchain Technology in Accounting Sphere. Academy of Accounting and Financial Studies Journal. 2019. Vol. 23(SI2). P. 1-6. Retrieved from https://www.abacademies.org/articles/Implementation-ofBlockchain-Technology-in-Accounting-Sphere-1528-263 5-23-SI-2-412.pdf. 30. Никифорук О.І., Стасюк О.М., Чмирьова Л.Ю., Федяй Н.О. Цифровізація в транспортному секторі: тенденції та індикатори розвитку. Частина 1. Статистика Украӥни. 2019. № 3. С. 70-81. https://doi.org/ 10.31767/su.3(86)2019.03.08. 31. Іванов C.B. Транспортно-логістичні кластери в контексті розвитку транспортної системи України та окремо взятого економічного району. Економічний вісник Донбacy. 2018. № 1(51). C. 15-22. 32. Dzwigol H., Aleinikova O., Umanska Y., Shmygol N., Pushak Y. An Entrepreneurship Model for Assessing the Investment Attractiveness of Regions. Journal of Entrepreneurship Education. 2019. Vol. 22(SI1). P. 1-7. 33. Trushkina N.V., Rynkevich N.S. Proposals for the creation of the appropriate institutional conditions of the formation and development of logistic clusters in the economic regions of Ukraine. Економічні інновації: зб. наук. праць. Т. 21. Вип. 3(72). Одеса: Ін-т проблем ринку та економікоекологічних досліджень НАН України, 2019. С. 138149. https://doi.org/10.31520/ei.2019. 21.3(72).138-149. 34. Іванов С.В., Ляшенко В.І., Трушкіна Н.В. Особливості розвитку транспортно-логістичної системи Придніпровського економічного району. Регіональна економіка та управління. 2019. № 3(25). С. 22-27. 35. Trushkina N., Rynkevich N. Optimization of information flows in transport logistics [Оптимизация информационных потоков в транспортной логистике]. Contemporary issues of sustainable development: monograph / Edited by T. Pokusa, O. Nestorenko. Opole: The Academy of Management and Administration in Opole, 2019. P. 137-146. 36. Іванов С.В., Ляшенко В.I., Трушкіна Н.В. Передумови формування та перспективи розвитку транспортно-логістичного кластера в Причорноморському економічному районі. Причорноморські економічні студї. 2019. Вип. 46. Ч. 2. С. 16-24. https://doi.org/10.32843/bses.46-25. 37. Транспорт i зв'язок України у 2010 році: стат. збірник. Київ: Державна служба статистики України, 2011. 267 с. 38. Транспорт і зв'язок України у 2018 році: стат. збірник. Київ: Державна служба статистики України, 2019. $154 \mathrm{c}$. 


\section{References}

1. Blaik P. (2010). Logistyka. Koncepcja zintegrowanego zarzadzania [Logistics. The concept of integrated management]. Warszawa, Polskie Wydawnictwo Ekonomiczne. 480 p. [in Polish].

2. Kotler P., Keller K.L. (2014). Marketing Management. 14th ed. Upper Saddle River, New Jersey, Prentice Hall. 720 p.

3. Merfi Pol R., Vud Donal'd F. (2017). Sovremennaya logistika [Modern Logistics]. 8th ed. Moscow, Williams [in Russian].

4. Bowersox Donald J., Kloss David J. (2017). Logistika: integrirovannaya tsep' postavok [Logistics: Integrated Supply Chain]. 2nd ed. Moscow, Olymp-Business [in Russian].

5. Dźwigoł H., Dźwigoł-Barosz M. (2018). Scientific Research Methodology in Management Sciences. Financial and Credit Activity: Problems of Theory and Practice, Vol. 2, No. 25, pp. 424-437. https://doi.org/ 10.18371/fcaptp. v2i25.136508.

6. Hryhorak M.Yu. (2017). Intelektualizatsiia rynku lohistychnykh posluh: kontseptsii, metodolohiia, kompetentnist [Intellectualization of the logistics services market: concepts, methodology, competence]. Kyiv, Sik Group Ukraine [in Ukrainian].

7. Perebyinis V.I., Perebyinis O.V. (2006). Transportno-lohistychni systemy pidpryiemstv: formuvannia ta funktsionuvannia [Transport-logistic systems of enterprises: formation and functioning]. Poltava: RVTs PUSKU [in Ukrainian].

8. Perebyinis V.I., Boldyrieva L.M., Perebyinis O.V. (2009). Transportnyi menedzhment i transportnyi marketynh vyrobnycho-komertsiinoi diialnosti [Transport management and transport marketing of production and commercial activity]. Poltava. Poltava University of Consumer Cooperation of Ukraine [in Ukrainian].

9. Nykyforuk O.I. (Ed.). (2017). Rozvytok infrastrukturnykh sektoriv yak chynnyk realizatsii priorytetnykh napriamiv ekonomichnoi polityky Ukrainy [Development of infrastructure sectors as a factor of realization of priority directions of economic policy of Ukraine]. Kyiv, State Institution «Inst. and predicted. NAS of Ukraine [in Ukrainian]

10. Ivanov S.V., Kharazishvili Yu.M. (2017). Innovatsiini faktory rozvytku transportnoi systemy Ukrainy [Innovative factors of development of the transport system of Ukraine]. Visnyk ekonomichnoi nauky Ukrainy / Bulletin of Economic Science of Ukraine, 2, pp. 47-55 [in Ukrainian].

11. Ivanov S.V., Liashenko V.I., Trushkina N.V. (2019). Innovatsiinyi rozvytok transportno-lohistychnoi systemy v Ukraini: problemy ta shliakhy yikh vyrishennia [Innovative development of the transport and logistics system in Ukraine: problems and solutions]. Instytutsionalna model innovatsiinoi ekonomiky / Institutional model of innovation economy, pp. 114-130. Kyiv, IIE of NAS of Ukraine [in Ukrainian].

12. Trushkina N. (2019)/ Financial ensuring mechanism of management innovative development of the transport-logistics system. Organizational-economic mechanism of management innovative development of economic entities: collective monograph / Edited by M. Bezpartochnyi, in 3 Vol. / Higher School of Social and Economic. Przeworsk, WSSG. Vol. 3, pp. 227-236.
13. Nykyforuk O.I. (2014). Modernizatsiia nazemnykh transportnykh system Ukrainy [Modernization of land transport systems of Ukraine]. Kyiv, Institute of Economics and Forecasting of NAS of Ukraine [in Ukrainian].

14. Zrobek J. (2011). Marketing w klastrach logistycznych. Acta Universitatis Lodziennsis. Folia Oeconomica. 251, pp. 5-16 [in Polish].

15. Szuster M. (2012). Rola klastrow we wspieraniu innowacyjnosci [The role of clusters in innovation supporting]. Ekonomiczne Problemy Uslug, 94, pp. 311325 [in Polish].

16. Smyrnov I., Shmatok O. (2012). Formuvannia transportno-lohistychnykh klasteriv u YeS: ukrainskyi kontekst [Formation of transport and logistics clusters in the EU: Ukrainian context]. Visnyk Kyivskoho natsionalnoho universytetu imeni T.H. Shevchenka / Bulletin of the TG Kiev National University Shevchenko, Issue 60, pp. 14-19 [in Ukrainian].

17. Popova N.V. (2013). Klastery kak osnova innovatsionnogo razvitiya transportno-logisticheskoy sistemy regiona [Clusters as the basis for the innovative development of the transport and logistics system of the region]. Business Inform, Issue 8, pp. 63-67 [in Russian].

18. Aloshynskyi Ye.S., Bilan K.V. (2013). Rozrobka propozytsii shchodo stvorennia transportno-lohistychnoho klastera Kharkivskoi oblasti [Development of proposals for creation of transport and logistics cluster of Kharkiv region]. Vostochno-Yevropeyskiy zhurnal peredovykh tekhnologiy / East European Journal of Advanced Technology, 3(3), pp. 29-33 [in Ukrainian].

19. Kruczek M., Zebrucki Z. (2014). Koncepcja klastrow logistycznych [Conception of logistic clusters]. Zeszyty naukowe Politechniki Slaskiej. Seria: Organizacja i zarzadzanie, 70, pp. 229-241 [in Polish].

20. Voinarenko M.P. (Ed). (2014). Klastery v ekonomitsi Ukrainy [Clusters in the Economy of Ukraine]. Khmelnytskyi, KhNU, FOP Melnyk A.A. [in Ukrainian].

21. Poliakova O.M. (2014). Klasternyi pidkhid do formuvannia intehrovanoi transportno-lohistychnoi systemy [Cluster approach to the formation of an integrated transport and logistics system]. Visnyk ekonomiky transportu $i$ promyslovosti / Bulletin of Economics of Transport and Industry, 45, pp. 239-244 [in Ukrainian].

22. Frankowska M. (2015). Klastry logistyczne jako ogniwa globalnych lancuchow dostaw. Logistyka, 3, pp. 5633-5637 [in Polish].

23. Dmukhovski R. (2019). Poniattia lohistychnykh klasteriv ta efektyvnosti ekonomichnykh pidpryiemstv [The concept of logistics clusters and efficiency of economic enterprises.]. Zhurnal yevropeiskoi ekonomiky / Journal of the European Economy, Vol. 18, No. 3 (70), pp. 296-306 [in Ukrainian]. https://doi.org/10.35774/jec2019. 03.351 .

24. Gritsenko S.I. (2019). Modeliuvannia systemy tsinnostei ekolantsiuha postachan yak dominanta transportno-lohistychnykh klasteriv [Design of the system of values of eco-chain deliveries as dominant of transportlogistic clusters]. Visnyk ekonomichnoi nauky Ukrainy / Bulletin of Economic Science of Ukraine, 1(36), pp. 31-34 [in Ukrainian].

25. Hrytsenko V.I., Onyshchenko I.M. (2017). Vyznachennia informatyvnosti parametriv modeli prohnozuvannia ymovirnosti vyboru produktu v umovakh 
«Big Data» [Determination of informative parameters of the model of predicting the probability of product selection in the Big Data conditions]. Kibernetika i vychislitel'naya tekhnika / Cybernetics and computing, Issue 4 (190), pp. 518 [in Ukrainian].

26. Onyshchenko I.M. (2017). Udoskonalennia metodiv obrobky ta zberihannia danykh za dopomohoiu instrumentiv «Big Data» ta Map Reduce [Improve data processing and storage methods with Big Data and Map Reduce tools]. Ekonomiko-matematychne modeliuvannia sotsialno-ekonomichnykh system / Economic and mathematical modeling of socio-economic systems, Issue 22, pp. 159-178. Kyiv, MNNTsITS NAN ta MON Ukrainy [in Ukrainian].

27. Kwilinski A. (2018). Mechanism of formation of industrial enterprise development strategy in the information economy. Virtual Economics, Vol. 1, No. 1, pp. 7-25. https://doi.org/10.34021/ve.2018.01.01(1).

28. Kwilinski A. (2018). Mechanism of modernization of industrial sphere of industrial enterprise in accordance with requirements of the information economy. Marketing and Management of Innovations, 4, pp. 116128. http://doi.org/10.21272/ mmi.2018.4-11.

29. Kwilinski A. (2019). Implementation of Blockchain Technology in Accounting Sphere. Academy of Accounting and Financial Studies Journal, Vol. 23(SI2), pp. 1-6. Retrieved from https:/www.abacademies.org/ articles/Implementation-of-Blockchain-Technology-inAccounting-Sphere-1528-2635-23-SI-2-412.pdf.

30. Nykyforuk O.I., Stasiuk O.M., Chmyrova L.Yu., Fediai N.O. (2019). Tsyfrovizatsiia v transportnomu sektori: tendentsii ta indykatory rozvytku. Chastyna 1 [Digitization in the transport sector: trends and indicators of development. Part 1]. Statystyka Ukrainy / Statistics of Ukraine, 3, pp. 70-81. Retrieved from https://doi.org/ 10.31767/su.3(86)2019.03.08 [in Ukrainian].

31. Ivanov S.V. (2018). Transportno-lohistychni klastery $\mathrm{v}$ konteksti rozvytku transportnoi systemy Ukrainy ta okremo vziatoho ekonomichnoho raionu [Transport and logistic clusters in the context of the transport system development of Ukraine and special economic region]. Ekonomichnyi visnyk Donbasu / Economic Herald of the Donbas, 1(51), pp. 15-22 [in Ukrainian].

32. Dzwigol H., Aleinikova O., Umanska Y., Shmygol N., Pushak, Y. (2019). An Entrepreneurship Model for Assessing the Investment Attractiveness of Regions. Journal of Entrepreneurship Education, Vol. 22(SI1), pp. 1-7.

33. Trushkina N.V., Rynkevich N.S. (2019). Proposals for the creation of the appropriate institutional conditions of the formation and development of logistic clusters in the economic regions of Ukraine. Ekonomichni innovatsii / Economic Innovation, Vol. 21, Issue 3(72), pp. 138-149. Odesa, Institute of Market Problems and Economic and Environmental Research of NAS of Ukraine. https://doi.org/10.31520/ei.2019. 21.3(72).138149.

34. Ivanov S.V., Liashenko V.I., Trushkina N.V. (2019). Osoblyvosti rozvytku transportno-lohistychnoi systemy Prydniprovskoho ekonomichnoho raionu [Features of development of transport-logistical system of Pridneprovsky economic district]. Rehionalna ekonomika ta upravlinnia / Regional Economics and Management, 3(25), pp. 22-27 [in Ukrainian].
35. Trushkina N., Rynkevich N. (2019). Optimization of information flows in transport logistics. Contemporary issues of sustainable development: monograph (pp. 137146) / Edited by T. Pokusa, O. Nestorenko. Opole, The Academy of Management and Administration in Opole.

36. Ivanov S.V., Liashenko V.I., Trushkina N.V. (2019). Osoblyvosti rozvytku transportno-lohistychnoi systemy Prydniprovskoho ekonomichnoho raionu [Features of development of transport-logistical system of Pridneprovsky economic district]. Rehionalna ekonomika ta upravlinnia / Regional Economics and Management, Issue 46, P. 2, pp. 16-24 [in Ukrainian]. https://doi.org/ $10.32843 /$ bses.46-25.

37. Transport i zviazok Ukrainy u 2010 rotsi [Transport and Communications of Ukraine in 2010]. (2011). Kyiv, State Statistics Service of Ukraine [in Ukrainian].

38. Transport i zviazok Ukrainy u 2018 rotsi [Transport and Communications of Ukraine in 2018]. (2019). Kyiv, State Statistics Service of Ukraine [in Ukrainian].

Іванов С., Джвігол Х., Трушкіна Н. Пропозиції щодо формування транспортно-логістичного кластеру як інституту регіонального розвитку (на прикладі Донецького економічного району)

Одним 3 динамічних і стрімких напрямів розвитку сучасних регіональних екосистем $є$ транспортна логістика як ефективне джерело забезпечення конкурентних переваг. Це вимагає застосування нових інструментів підвищення конкурентоспроможності регіонів, серед яких кластерний підхід, суть якого полягає у формуванні й розвитку транспортно-логістичних кластерів шляхом консолідації зусиль держави, бізнесу, науки, освіти у пріоритетних сферах економічної діяльності.

Як показує міжнародна практика, реалізація кластерної моделі організації логістичної діяльності сприятиме скороченню загальних логістичних витрат на 12$35 \%$ у результаті зниження транспортних витрат на 7$20 \%$ і витрат на навантажувально-розвантажувальні роботи на 20-30\%, а також прискоренню швидкості обігу матеріальних ресурсів на 20-40\%.

Отже, формування транспортно-логістичних кластерів дозволить створити сприятливі умови задля зростання обсягів та якості наданих транспортно-логістичних послуг і сформувати якісно нову модель регіональної економіки.

У результаті дослідження виявлено, що формуванню й ефективному функціонуванню транспортнологістичного кластеру в Донецькому економічному районі перешкоджає безліч ключових бар'єрів, які умовно можна систематизувати за такими групами, як політичні, зовнішньоекономічні; інституційні; інвестиційно-фінансові; інфраструктурні; інформаційні; екологічні; логістичні. Доведено, що для ефективного розвитку транспортно-логістичного кластеру в економічному районі доцільно розробити пропозиції щодо створення належних інституційних умов, які полягають у доопрацюванні Стратегії регіонального розвитку в частині інституційного, інвестиційно-фінансового, організаційно-економічного й інформаційного забезпечення функціонування транспортно-логістичного кластеру з використанням кластерного підходу, а також Концепції створення транспортно-логістичного 
кластеру і Стратегії комплексного розвитку транспортно-логістичного кластеру як складової регіональної транспортно-логістичної системи; запровадженні механізму фінансового забезпечення, який включає екзогенні й ендогенні чинники, що впливають на розвиток регіональної транспортно-логістичної системи; принципи, на яких має базуватися формування транспортно-логістичного кластеру; функції управління (прогнозування, планування, організація, облік, контроль, аналіз, регулювання); сукупність інструментів, що регулюють умови організації й здійснення логістичної діяльності, а також надання транспортних послуг; фінансові інструменти (венчурне інвестування, краудінвестинг, факторинг, публічно-приватне партнерство на основі залучення приватних інвестицій, коштів кредитних установ, іноземних інвестиційних ресурсів, грантів міжнародних фінансових організацій); засоби (цифрові й інформаційно-комунікаційні технології, програмне забезпечення, нормативні документи).

Поєднання сучасної кластерної політики, механізму інституційного забезпечення розвитку інтегрованої транспортно-логістичної системи і стратегій розумних спеціалізацій промисловості в умовах децентралізації дозволить створити належні умови для формування транспортно-логістичного кластеру як дієвої форми партнерства, зміцнити конкурентні переваги Донецького економічного району і підвищити економічну спроможність територіальних громад.

Обгрунтовано, що впровадження пропозицій щодо створення належних інституційних умов формування й розвитку транспортно-логістичного кластеру в Донецькому економічному районі сприятиме одержанню синергетичного ефекту, складовими якого $\epsilon$ підвищення рівня інвестиційної привабливості району; збільшення надходжень до бюджету за рахунок економічного зростання територій; створення нових робочих місць і зростання рівня зайнятості; збільшення обсягів вантажоперевезень і вантажообігу; оптимізація переміщення логістичних потоків; зниження витрат на організацію логістичної діяльності через зменшення транспортної складової у вартості послуг, скорочення часу на виконання митних процедур при оформленні вантажів; забезпечення сприятливих умов функціонування ринку логістичних послуг; створення об'єктів необхідної логістичної інфраструктури (транспортної, торгівельної, сервісної тощо); удосконалення технології перевезень з використанням сучасних цифрових інформаційно-комунікаційних технологій.

Ключові слова: економічний район, транспортнологістичний кластер, інституційні умови, чинники, механізм фінансового забезпечення, логістична діяльність, синергетичний ефект.

Ivanov S., Dzwigol H., Trushkina N. Proposals for the Formation of a Transport and Logistics Cluster as an Institution of Regional Development (on the Example of Donetsk Economic Region)

One of the dynamic and rapid lines of development of modern regional ecosystems is transport logistics as an effective source of competitive advantages. This requires the use of new tools to improve the competitive ability of regions, including the cluster approach, the essence of which is the formation and development of transport and logistic clusters by consolidating the efforts of the state, business, science, education in priority fields of economic activity.

As international practice shows, the implementation of the cluster model of logistic activities will contribute to the reduction of total logistic costs by $12-35 \%$ as a result of reducing transport costs by $7-20 \%$ and the cost of handling operations by $20-30 \%$, as well as accelerating the speed of circulation of material resources by $20-40 \%$.

Therefore, the creation of transport and logistic clusters will create favorable conditions for the growth of the volume and quality of transport and logistics services and create a qualitatively new model of the regional economy.

It was found that the formation and effective functioning of transport and logistic cluster in the Donetsk economic region is hampered by many key barriers that can be conditionally classified into the following groups, such as political, foreign economic, institutional, investment and financial, infrastructure, environmental, information, logistics. It was proved that for the effective development of transport and logistic cluster in the economic region it is reasonable to develop proposals for the creation of appropriate institutional conditions, which are to finalize the Strategy of the regional development in terms of institutional, investment and financial, organizational and economic and information support of the functioning of transport and logistic cluster using the cluster approach, as well as the Concept of creating transport and logistic cluster and Strategy for the integrated development of transport and logistic cluster as a component of the regional transport and logistic system; implementation of the financial support mechanism, which includes exogenous and endogenous factors affecting the development of the regional transport and logistic system; the principles on which the formation of transport and logistic cluster should be based; management functions (forecasting, planning, organization, accounting, control, analysis, regulation); a set of tools governing the organization and implementation of logistic activities, as well as the provision of transport services; financial instruments (venture investment, crowdinvesting, factoring, public-private partnership on the basis of attracting private investments, funds of credit institutions, foreign investment resources, grants of international financial organizations); means (digital, information and communication technologies, software, regulatory documents).

Combination of modern cluster policy, mechanism of institutional support for the development of an integrated transport and logistic system and strategies of smart industry specializations in the context of decentralization will create the appropriate conditions for the formation of transport and logistic cluster as an effective form of partnership, strengthen the competitive advantages of the Donetsk economic region and increase the economic capacity of territorial communities.

It was substantiated that the introduction of proposals for the creation of the appropriate institutional conditions for the formation and development of transport and logistic cluster will contribute to a synergetic effect, the components of which are to increase the level of investment attractiveness of economic region; increase revenues due to economic growth of territories; creation of new jobs and growth of employment; increase in the volume of cargo transportation and turnover; optimization of movement of logistic flows; cost reduction for the organization of lo- 
gistic activities for the reduction of transport component in the cost of services, reduction in time to complete customs procedures for clearance of goods; provision of favorable conditions for the functioning of logistic market; creating objects of the appropriate logistic infrastructure (transport, trade, service, etc.); improvement of the technology of transportation with the use of modern digital information and communication technologies.

Keywords: economic region, logistic cluster, institutional conditions, factors, financial support mechanism, logistic activities, synergetic effect.

Иванов С., Джвигол Х., Трушкина Н. Предложения по формированию транспортно-логистического кластера как института регионального развития (на примере Донецкого экономического района)

Одним из динамичных и интенсивных направлений развития современных региональных экосистем является транспортная логистика как эффективный источник обеспечения конкурентных преимуществ. Это требует применения новых инструментов повышения конкурентоспособности регионов, среди которых кластерный подход, суть которого заключается в формировании и развитии транспортно-логистических кластеров путем консолидации усилий государства, бизнеса, науки, образования в приоритетных сферах экономической деятельности.

Как показывает международная практика, реализация кластерной модели организации логистической деятельности будет способствовать сокращению общих логистических издержек на $12-35 \%$ в результате снижения транспортных затрат на 7-20\% и затрат на погрузочно-разгрузочные работы на 20-30\%, а также ускорению скорости обращения материальных ресурсов на $20-40 \%$.

Таким образом, формирование транспортно-логистических кластеров позволит создать благоприятные условия для роста объемов и качества предоставляемых транспортно-логистических услуг и сформировать качественно новую модель региональной экономики.

В результате исследования выявлено, что формированию и эффективному функционированию транспортно-логистического кластера в Донецком экономическом районе препятствует множество ключевых барьеров, которые условно можно систематизировать по следующим группам, как политические, внешнеэкономические; институциональные; инвестиционно-финансовые; инфраструктурные; информационные; экологические; логистические. Доказано, что для эффективного развития транспортно-логистического кластера в экономическом районе целесообразно разработать предложения по созданию надлежащих институциональных условий, которые заключаются в доработке Стратегии регионального развития в части институционального, инвестиционно-финансового, организационно-экономического и информационного обеспечения функционирования транспортно-логистического кластера с использованием кластерного под- хода, а также Концепции создания транспортно-логистического кластера и Стратегии комплексного развития транспортно-логистического кластера как составляющей региональной транспортно-логистической системы; реализации механизма финансового обеспечения, который включает экзогенные и эндогенные факторы, влияющие на развитие региональной транспортно-логистической системы; принципы, на которых должно базироваться формирование транспортно-логистического кластера; функции управления (прогнозирование, планирование, организация, учет, контроль, анализ, регулирование); совокупность инструментов, регулирующих условия организации и осуществления логистической деятельности, а также предоставление транспортных услуг; финансовые инструменты (венчурное инвестирование, краудинвестинг, факторинг, публично-частное партнерство на основе привлечения частных инвестиций, средств кредитных учреждений, иностранных инвестиционных ресурсов, грантов международных финансовых организаций); средства (цифровые и информационно-коммуникационные технологии, программное обеспечение, нормативные документы).

Сочетание современной кластерной политики, механизма институционального обеспечения развития интегрированной транспортно-логистической системы и стратегии разумных специализаций промышленности в условиях децентрализации позволит создать надлежащие условия для формирования транспортнологистического кластера как действенной формы партнерства, укрепить конкурентные преимущества Донецкого экономического района и повысить экономическую состоятельность территориальных общин.

Обосновано, что внедрение предложений по созданию надлежащих институциональных условий формирования и развития транспортно-логистического кластера в Донецком экономическом районе будет способствовать получению синергетического эффекта, составляющими которого являются повышение уровня инвестиционной привлекательности района; увеличение поступлений в бюджет за счет экономического роста территорий; создание новых рабочих мест и рост уровня занятости; увеличение объемов грузоперевозок и грузооборота; оптимизация перемещения логистических потоков; снижение затрат на организацию логистической деятельности из-за уменьшения транспортной составляющей в стоимости услуг, сокращения времени на выполнение таможенных процедур при оформлении грузов; обеспечение благоприятных условий функционирования рынка логистических услуг; создание объектов необходимой логистической инфраструктуры (транспортной, торговой, сервисной и т.п.); совершенствование технологии перевозок с использованием современных цифровых информационно-коммуникационных технологий.

Ключевые слова: экономический район, транспортно-логистический кластер, институциональные условия, факторы, механизм финансового обеспечения, логистическая деятельность, синергетический эффект.

Received by the editors: 02.12 .2019 and final form 19.12.2019 